\title{
Skills Needed by New Accounting Graduates in a Rapidly Changing Technological Environment
}

\author{
Linda Bressler \\ Southeastern Oklahoma State University \\ Diana Pence \\ University of Houston-Downtown
}

\begin{abstract}
Current research indicates that newly-hired accounting graduates may lack some of the skills necessary to be successful in their chosen profession. This paper examines recent research to determine what skills are needed by accounting graduates. A number of papers suggest that accounting graduates may not have the soft skills, such as analytical thinking skills and communication skills, necessary to succeed. This may be due in part to differences between Millennial students and students of prior generations This paper concludes by examining specific skills needed by accounting graduates and who should be responsible for providing those skills-universities, employers, or both.
\end{abstract}

\section{INTRODUCTION}

Research indicates that newly-hired accounting graduates may not possess the skills needed to be successful (Anderson \& Baur, \& Griffith, 2017; Macdermott \& Ortiz, 2017; Succo, 2015; Shotzik, 2016). Responses from recruiters, hiring managers, and professors seem to be assessing blame on one another with minimal discussion as to why graduating students need additional skills to obtain and retain professional accounting positions. Some researchers note the reason can be explained because educators do not keep up with the necessary technological skills in a highly-changing hi-tech environment (Daigle, Hayes \& Hughes, 2007; Jackling \& DeLange, 2009; McCafferty, 2018; Rindasu, 2016). Other researchers believe that students possess the technical accounting skills, but graduate from universities with limited soft skills (Macdermott \& Ortiz, 2017). Still, a few researchers give the explanation that graduating student deficits occur because the Millennials and Generation X graduates grew up in a very different home environment than graduates of years ago and Millennials failed to learn the soft skills of those students graduating 20 years ago (Allen \& Jackson, 2017; Anderson, 2016; Danford, 2013; Kumaria \& Bhattgjms, 2015; Millennials in the Workplace, 2016; Tulgan, 2015); . Concerns for the readiness of new Accounting graduates as well as readiness of experienced auditors continue.

\section{TERMS}

Flipped Classroom is an instructional strategy and a type of blended learning that reverses the traditional learning environment by delivering instructional content, often online, outside of the 
classroom. It moves activities, including those that may have traditionally been considered, from homework, into the classroom. In a flipped classroom, students watch online lectures, collaborate in online discussions, or carry out research at home while engaging in concepts in the classroom with the guidance of a mentor. (Flipped classoom (n.d.). In Wikipedia. Retrieved August 17, 2018)

Generation $\mathbf{X}$ - Generation X, or Gen X, is the demographic cohort following the baby boomers and preceding the Millennials. There are no precise dates for when Generation $\mathrm{X}$ starts or ends. Demographers and researchers typically use birth years ranging from the early-to-mid 1960s to the early 1980s. (Generation X (n.d.). In Wikipedia. Retrieved August 15, 2018, from https://en.wikipedia.org/wiki/ Generation_X)

Millennials - (also known as Generation Y) are the generational demographic cohort following Generation X. There are no precise dates for when this cohort starts or ends; demographers and researchers typically use the early 1980 s as starting birth years and the mid-1990s to early 2000s as ending birth years. Millennials are sometimes referred to as "echo boomers" due to a major surge in birth rates in the 1980s and 1990s, and because Millennials are often the children of the baby boomers. (Millennials (n.d.). In Wikipedia. Retrieved August 15, 2018, from

https://en.wikipedia.org/wiki/Millennials).

Reverse mentoring - refers to an initiative in which older executives are paired with and mentored by younger employees on topics such as technology, social media and current trends. Reverse mentoring (n.d.). In Wikipedia. Retrieved August 15, 2018, from

https://www.techopedia.com/definition/28107/reverse-mentoring

Soft skills are a combination of people skills, social skills, communication skills, character traits, attitudes, career attribute, ${ }^{[1]}$ social intelligence and emotional intelligence quotients among others that enable people to navigate their environment, work well with others, perform well, and achieve their goals with complementing hard skills. (Soft Skills (n.d.). In Wikipedia. Retrieved August 15, 2018, from https://en.wikipedia.org/wiki/Soft_skills).

Teeter - to appear to be about to fall while moving or standing: They teetered around the room like two toddlers, helpless with laughter. FIG. The city is teetering on the brink/edge of (= dangerously close to) a financial calamity. (Teetered (n.d.) in The Cambridge Dictionary, Retrieved August 17, 2018 from https://dictionary.cambridge.org/us/dictionary/english/teeter)

\section{SKILLS NEW ACCOUNTING GRADUATES MAY NEED}

Many more companies will be investing in technology as the software prices decrease at the same time that systems offer more options to aid managers in handling their companies' resources. Researchers in past years asked the question whether newly-graduated accountants and auditors are ready for these changes (Berlin, 2017; Daigle \& Hayes, \& Hughes, 2007; Jackling \& De Lange, 2009; Pan \& Seow, 2016; Shoztic, 2016; Vasarhelyí, et al. 2014). Concerns for the readiness of new Accounting graduates as well as readiness of experienced auditors continue to be an issue.

Pan \& Seow (2016) noted that the emergence of cloud computing, eXtensible Business Reporting Language (https://en.wikipedia.org/wiki/XBRL), and business analytics could mean extensive training for accountants in order to keep up with the changing technology. The authors indicate that the accounting industry needs experts in highly technical accounting information systems (AIS) in order to deal with these new demands which may require changes in universities' accounting curriculum.

The AICPA website defines competencies students will need when they enter their accounting careers (https://www.aicpa.org/interestareas/accountingeducation/resources/corecompetency.html -- 2018). These

competencies include Accounting, Professional, and Business Competencies. The Accounting Competencies deal with risk assessment, technology, and systems design and the ability to effectively utilize business systems. The Professional Competencies include displaying a professional manner, working in teams, as well as communication and listening skills. The Business Competencies included governance, global and industry factors, and an overall strategic perspective. 
Vasarhelyi, et al (2014) wrote auditors need to be able to audit companies utilizing enterprise resource planning (ERP) systems. The AICPA Assurance Services Executive Committee developed new data standards called Audit Data Standards (ADS) and planned to work with vendors to fully automate existing audit tools utilizing these standards. Auditors often find requesting data one of the most difficult tasks during an audit visit and the authors indicate the new ADS standards could help with "...integrating analytics with judgement..." (Varsarhelyi, et al., 2014 p. 35). However, auditors will need the skillset in order to access big data from these data apps or software packages.

Spraaakman, et al (2015) asked three questions: (1) What IT knowledge and skills do employers expect of new management accounting graduates? (2) What level of knowledge and skill are expected of the graduates? (3) How will the graduates be expected to use that knowledge and skill? The authors suggested that new management accounting graduates were expected to have immediate ability to use some Microsoft tools, particularly Excel, and to have adequate knowledge of an ERP system in order to navigate the system and to analyze data from the system.

Boulianne (2016) addressed the level of information technology (IT) education that should be included in accounting programs. The author found that there was evidence to suggest that an advanced level of IT education is important for accountants, but acknowledged that there are challenges to incorporating increased IT education into accounting programs. The author suggests that it is time consuming to develop practical exercises which may not be usable in future courses due to constantly changing technology. Also, faculty may not be adequately recognized or incentivized for curriculum development due to the focus on research for recruitment, tenure, and promotion decisions of faculty.

Gonzalez and Hoffman (2017) noted the importance of continuous auditing which can be an important process for fraud prevention and detection which could significantly decrease effective fraud attacks. But auditors often need to aid in the design and interpretation of the results given by continuous auditing software which means that the auditor must be skilled in comprehending continuous auditing reports and/or alerts. In addition, auditors should possess the appropriate skill set to identify new fraud schemes and be able to effectively assess new alerts especially during the initial system implementation.

\section{SOFT SKILLS NEEDED}

Other researchers noted that changing technology also requires other more sophisticated skills as well. Shoztic et al. (2016) indicated that future auditors will need, in addition to technology skills, a deep understanding of the financial reporting environment. They will also need more than a superficial understanding of the industry they will be auditing and should be able to demonstrate a critical thinking skillset. The authors believed that future auditors do not need to be information technology experts, but will need the following technical and soft skills:

- data mining

- data risk assessment (including data security and integrity)

- being able to work with relational and non-relational databases

- applying and interpreting statistical methods and advanced analytics (turning raw data into usable information)

- using visualization to present complex data analysis in a written narrative (p. 42)

Although Shoztic, et al., (2016) concentrated on future technology skills, the authors also mentioned needed communication skills. Gray (2010) concurs that graduating students need communication skills, but noted that much of the research conducted on student communication skills was not very specific although feedback from employers consistently indicated overall that they valued oral communication skills or "oral competency" in their newly-hired accounting staff. But what does that mean? The authors sought to answer that question in their longitudinal study where questionnaires were sent to all New Zealand chartered accountancy firms specifically asking what type of required oral communication skills are needed, how often do their new hires/interviewees possess these skills, and the importance of applicants demonstrating these skills during the interview and in the early years of their careers. The 
result of the first phase of their study noted a large gap between the reported importance of these skills and actual skills demonstrated by new hires/interviewees. Further results included their overall dissatisfaction with listening and speaking skills, as well as English language competency. In particular, the employers wished new accounting hires to demonstrate skills in "asking for clarification or feedback from management....conveying an attitude of respect and interest in clients, and describing situations accurately and precisely to superior(s)" (p. 53) but here also could be found a large discrepancy from skills employers desired and skills new hires demonstrated.

Cicekli (2016) studied needed skills of graduates, specifically in banking. The author believed that companies look for graduates with skills, but also look for a new hire's qualities or soft-skills as well. The author mentioned the need for new hires to possess soft skills such as personality characteristics, attitude, people skills, problem-solving skills, learning, self-management and decision-making and timemanagement skills as well. Cicekli (2016)'s study included qualitative interviews with managers of banks that hired minimally four new graduates per year. The managers were asked questions on what skills they believed new hires should possess, do they believe universities' business curriculum provide their graduates with skills needed to work in banking and which skills could the universities do a better job of providing to new graduates planning to work in banking. The results of the study indicated that the managers do not believe universities provide the skills needed to students working in banking. The top 7 skills sought by hiring managers included analytical thinking skills, foreign languages, computer skills, communication skills, team work and persuasion skills. The author concluded by noting that universities need to not only provide students technical skills, but many of the soft skills such as analytical thinking and communication skills.

Other researchers found that, in addition to technology and communication skills, accounting firms also looked for new hires to be team players (Lim et al., 2016). The authors noted that future accountants will need what they called "employability skills" (p.185) and some of these skills included technical accounting skills and knowledge and personal attributes (Succi, 2015). No longer can accountants sit in their cubicle with the minimal skill set gathered from a typical accounting curriculum. The authors believed that future accountants also need to possess the soft skills such as emotional intelligence, independence, flexibility, listening responsiveness, and listening attentiveness. In addition, the authors noted the importance of shared vocabulary and suggested that universities adjust their curriculum to include these skills being taught to increase employability of their graduates.

\section{WHY A SOFT SKILLS GAP?}

Allen and Jackson (2017) suggested that those individuals involved with teaching and training Millenials must first attempt to understand the experiences that shaped these individuals to more effectively facilitate learning. The researchers indicate that Millennials believe they are special and this belief many times would be encouraged in school as well. It did not help that this was the generation of "helicopter parents" (Allen and Jackson, 2017, p.4; Anderson, 2016, p.1) which might have affected Millennials' ability to independently solve problems. In addition, Allen and Jackson (2017) called these individuals "the Trophy Generation" (p.4) which may be why many times these individuals expect continuous feedback in the workplace and may have unrealistic expectations of their supervisors and coworkers.

Scarpati and Johnson (2012) cited findings of Richard Sweeney (University Librarian, New Jersey Institute of Technology) that were presented at NYSSCPA's 2012 Higher Education Conference. Sweeney examined how millennial behavior differs from previous generations at the same age. He found that Millennials are impatient and cannot tolerate delays, require constant feedback, prefer to learn by doing, value free time more than compensation, and require more flexibility than prior generations.

In regard to their lack of soft skills, Anderson (2016) faults helicopter parents for their childrens' lack of soft skills. The author suggests looking back to the prior generation of children who dealt with latchkey parenting and stated that no one validated the Gen Xers' feelings and, because these Gen Xers are now parents, they probably overly-validated their Millennial childrens' feelings. Anderson also goes on to say 
that adults catered to the Millennial's needs continuously. They weren't told to go outside to play or forced to entertain themselves (as their parents did). These activities could have helped these children develop their curiosity, trial by error decision-making skills, etc. Instead these children appeared to be "over-stimulated, overscheduled, and [sometimes] over-medicated" (Anderson, 2016 p.1). In addition, these Millennials grew up extensively utilizing cell phones, instant messaging and Facebook technology and thus appeared to be the "teetered generation" (Allan \& Jackson, 2017, p.5) because of their constant connection to technology, social media and their parents. Researchers indicate once those involved with teaching, training and working with Millennials understand these individuals better, it can be a good start to planning what may work to bridge the Millennial soft-skills deficit.

\section{WHAT CAN BE DONE?}

It can be interesting to note that some CPA firms' consulting endeavors involve training their clients' staff on soft skills. Vogalsong (2018) spoke of a York County CPA firm helping clients to acquire the soft skills needed in business today. The author mentioned how a partner in York County who believed that clients need assistance in more than just the financial area in order to maximize client success when dealing with the constantly-changing business environment today. This includes helping their staff increase or acquire those soft skills.

Pernsteiner (2015) examined hard and soft skill development in accounting students that completed internships. The author surveyed accounting majors using an instrument based on 11 soft and hard skills identified by employers in prior research as required for new accounting graduates. They are: (1) confidence in ability, (2) working independently, (3) working with others, (4) writing effectively, (5) communicating with others, (6) understanding technical aspects of the profession, (7) time management, (8) speaking in front of others, (9) analyzing data, (10) using judgement in completing tasks, and (11) using Excel or other computer software. The majority of students who completed internships felt it was an essential part of their accounting education. Many students made progress in the development of some of the skills valued by employers during their internships, but there was less progress in the highly value areas of written communication and speaking in front of others. The author suggests that accounting programs should require students to complete an internship. Accounting educators should also encourage students to participate in high-impact practices to develop soft skills such as communication and written skills.

Weaver and Kulesza (2014) found that employers demand problem-solving skills, critical thinking skills, and both written and oral communication skills in new accounting hires. They suggest incorporating additional classroom activities into accounting courses including:

1) A changing conditions paper and discussion that would hone students' critical thinking skills.

2) A team exercise to compare and contrast the financial analysis of public companies requiring students to use critical thinking skills.

3) A discussion board for online accounting classes that would require students to explore peripheral topics discussed by accountants and clients. This would require students to use their critical thinking skills, problem-solving skills, and writing skills.

4) Article summaries to provide a link between theory and practice while improving writing skills.

5) Team-based simulations to provide collaborative opportunities to use acquired knowledge in solving problems.

6) Traditional and mini-case studies introduced that increase in complexity as the students progress from introductory to advanced courses. The cases could be used to improve problem solving, working as a team member, and creative discussion.

7) Ethical debates to provide an opportunity for students to research a topic and present arguments in support of the position they have been assigned.

Caccaiolatti, Lee, and Molinero (2017) believed that universities need to step up to "...find their strategic position in the knowledge economy...by meeting the future skills demand..." (p. 2), and the 
research notes several universities who have planned to deal with the soft-skill deficit of their graduates. McCafferty (2018) spoke of the University of Akron who announced their intention to build a Professional Development Center in order to aid students needing better soft skills. Kent State planned to build a new College of Business building, keeping in mind a design that would facilitate the teaching of soft skills as well as business technical skills. This would update their old building built in the 1970's which mostly included classrooms that boasted fixed desks and set up in a tiered structure which inhibited team building projects and activities.

Tulgan (2015) tells the story about a group of Peace Corp managers and described how apparent helicopter parents of Peace Corp volunteers contacted Peace Corp administrators suggesting changes in their children's meals and lodgings. The researcher has been studying young individuals in the workplace since 1993 which included surveys and interviews in longitudinal studies. The results indicate a technical skills gap, as well as a generational difference in the soft skills gap in today's young workforce. Tulgan (2015) suggested a 5-step plan to help bridge the soft-skills gap:

1) Employers need to first ask themselves which soft skills will be important to them.

2) Make soft-skills an important skill in your HR training endeavors.

3) Build soft skills training into your hiring requirements and ensure that all in the organization understand that soft skills will be just as important as technical skills.

4) Remember these new graduates grew up with technology so a "just-in-time" online training software would be very helpful.

5) Require managers to embed soft-skills coaching into their team interactions and one-to-one communications with their staff and reward those who do so.

Phillips and Trainor (2014) suggest that, due to the unique characteristics of millennials, the flipped classroom approach to instruction may meet the needs and expectations of this group of students. In-class lectures are replaced by audio or visual lectures that are accessed online. Students are expected to watch the videos prior to class. Class time can then be devoted to experiential-learning activities. A survey of accounting students at a metropolitan university found that students prefer active learning to a lecture and/or PowerPoint presentations.

Crosley (2018) suggests that Millennials and Baby Boomers can work together and help one another. The author suggests reverse mentoring and indicates that Millennials bring with them skills that existing staff may not possess. At Hosokawa Micron, they utilize reverse mentoring as a strategy to encourage the two generations to work successfully together. The author indicates that both the mentors and mentees demonstrated enthusiasm for learning, and they built a mutual respect which resulted in enhanced cooperation and idea sharing in the workplace. Brian, the experienced employee at Hosokawa Micron said "with age comes wisdom... but I'll admit, sometimes it comes with an unwillingness to adopt change and the occasional blind spot." Brian noted that, with reverse mentoring, he became more willing to deal with modern technology. He stated that his existing skills [soft skills] that were learned in the workplace, will still be needed in the future, but he can still learn "new tricks" (p. 47) and that he learns something new every day and that "virtual showrooms, Twitter feeds and blogs are not only part of my vocabulary, they are now part of my everyday toolbox" (p.47). Jackson, the new employee noticed his industry technical skills improving because of the reverse mentoring and his soft skills improved as well because of Bryan's encouragement “... One day when I heard myself speaking with people on the phone, I realized I sounded....way more positive, more confident....so professional.....and I felt the customer respond to this. That is when I knew [Bryan]'s mentoring plus my increased project handling knowledge were paying off." (p. 48). As auditors and accountants will usually be assigned to mentors during their first year, perhaps reverse mentoring could work to help bridge the soft-skill gap in the Accounting industry.

Employers note often that newly-graduated accounting students lack some of the more employability or soft skills. It appears that upon graduation, these new hires possess adequate accounting textbook knowledge, but the research indicates that employers believe that many of the soft-skills are missing. Where should the intervention be done? In the late 1990's, research noted that faculty should "teach the students we have" (Bressoud, 1999; Hallett, 2000 (p. 3), Wrong \& Incognita, 2009). This phrase can still be found in university handbooks today (Kinzie \& Arcelus, 2015). The research indicates it may help 
faculty members to understand Millennials' learning style and possibly tweak their courses to meet these students' needs.

\section{CONCLUSIONS}

Extant research suggests that accounting graduates may not possess the requisite skills needed to be successful in their chosen profession. In particular, they may not have the soft skills necessary to succeed. This may be due to differences between Millennial students and students of prior generations and should be considered when developing the accounting curriculum. Graduates of accounting programs need to have both technical skills and soft skills such as analytical thinking skills and communication skills.

Who should be responsible for providing the skills needed by current graduating accounting students so that they may be successful in their chosen profession? The appendix summarizes the current literature regarding this responsibility. Universities should be responsible for teaching the following skills: applying and interpreting statistical methods, maintaining an attitude of respect to clients, continuous auditing, data mining, ERP systems, English language competency, highly technical AIS systems, and time-management skills. Employers should be responsible for teaching the following skills: business analytics, displaying a professional manner, foreign languages, listening skills, persuasion skills, problem-solving skills, relational databases, strategic prospective, and working in teams. Both employers and universities should be responsible for the following skills: displaying a professional manner, ERP systems, foreign languages, problem-solving skills, relational databases, and working in teams.

\section{FUTURE RESEARCH}

Several questions remain. Is there a disconnect between the technical and soft skills required by employers for new accounting graduates and the skills possessed by graduates of universities? What can universities do to minimize the expectations gap and what is covered in the traditional accounting curriculum? Should more universities deal with the soft-skill gap by creating soft-skills training facilities to bridge the gap between the skills employers require and the skills students possess by graduation? Is the answer as simple as companies hiring a CPA or specialized soft-skills firm to conduct training sessions on the needed soft skills? Should there be more collaboration between industry and universities to define a set of skills needed by new accounting graduates that could be incorporated into the accounting curriculum? Do employers have any responsibility to help their new employees acquire the needed employability skills and should businesses accommodate new millennial Accounting graduates who begin their careers without the soft skills needed today?

\section{REFERENCES}

Allen, R. N., \& Jackson, A. R. (2017). Contemporary Teaching Strategies: Effectively Engaging Millennials across the Curriculum. University Of Detroit Mercy Law Review, $1,1$.

Anderson, H. (2016). Millennials Lack Soft Skills and It's Your Fault. Credit Union Times, $27(5), 4$.

Anderson, H. J., Baur, J. E., Griffith, J. A., \& Buckley, M. R. (2017). What works for you may not work for (Gen) Me: Limitations of present leadership theories for the new generation. The Leadership Quarterly, 28(1), 245-260.

Berlin, O. (2017). Automation Nation: Will advances in technology put people out of work or give them new purpose? State Legislatures, 43(9), 8-12.

Boulianne, E. (2016). How should information technology be covered in the accounting program? Canadian Journal of Administrative Sciences, 33, 304-317.

Bressoud, D. M. (1999). Personal thoughts on mature teaching. How to teach mathematics, 173-181.

Cacciolatti, L., Lee, S. H., \& Molinero, C. M. (2017). Clashing institutional interests in skills between government and industry: An analysis of demand for technical and soft skills of graduates in the UK. Technological Forecasting and Social Change, 119, 139-153. 
Cicekli, E. (2016). Graduate skills requirements for effective performance in the banking sector. Business: Theory \& Practice, 17(4), 317-324. doi:10.3846/btp.17.11127

Crosley, I. (2018). Millennials Teach Baby Boomers a Lesson: How reverse mentoring is bridging the generational skills gap while encouraging fresh thinking. TCE: The Chemical Engineer, (924), 46-48

Daigle, R. J., Hayes, D. C., \& Hughes, K. (2007). Assessing student learning outcomes in the introductory accounting information systems course using the AICPA's core competency framework. (American Institute of Certified Public Accountants). Journal of Information Systems, 1.

Danford, N. (2013). Welcome the Millennials: as a new generation enters the workforce, publishers are changing with the times; a new crop of titles helps Millennials find success--without punching clocks, climbing ladders, or thinking outside of the box. Publishers Weekly, 20, 22.

Gauthier, L. (2016). Redesigning for Student Success: Cultivating Communities of Practice in a Higher Education Classroom. Journal of The Scholarship Of Teaching \& Learning, 16(2), 1-13. doi:10.14434/josotl.v16i2.19196

Gonzalez, G. C., \& Hoffman, V. B. (2018). Continuous Auditing's Effectiveness as a Fraud Deterrent. Auditing: A Journal of Practice \& Theory, 37(2), 225-247. doi:10.2308/ajpt-51828

Gray, F. (2010). Specific Oral Communication Skills Desired in New Accountancy Graduates. BUSINESS COMMUNICATION QUARTERLY, (1). 40.

Hallett, D. H. (2000). Teaching quantitative methods to students of public affairs: Present and future. Journal of Policy Analysis and Management, 19(2), 335-341.

Herchel, S. J. (2016). Millennial-aged adults learning online: Factors impacting academic success. Adult Education Research Conference. Retrieved from http://newprairiepress.org/aerc/2016/papers/21 https://en.wikipedia.org/wiki/XBRL

Jackling, B., \& De Lange, P. (2009). Do Accounting Graduates' Skills Meet The Expectations of Employers? A Matter of Convergence or Divergence. Accounting Education - London, (4-5), 369.

Jones, M., Baldi, C., Phillips, C., \& Waikar A. (2016). The Hard truth about soft skills: What recruiters look for in business graduates. College Student Journal, 50(3), 422-428.

Kinzie, J., \& Arcelus, V. (2015). Understanding campus environments. The Handbook of Student Affairs Administration, 49.

Kumari, A., \& Bhattgjms, A. (2015). Global Journal of Multidisciplinary Studies, 4(11), 1-14.

Lim, Y., Lee, T. H., Yap, C. S., \& Ling, C. C. (2016). Employability skills, personal qualities, and early employment problems of entry-level auditors: Perspectives from employers, lecturers, auditors, and students. Journal of Education for Business, 91(4), 185. doi:10.1080/08832323.2016.1153998

MacDermott, C., \& Ortiz, L. (2017). Beyond the Business Communication Course: A Historical Perspective of the Where, Why, and How of Soft Skills Development and Job Readiness for Business Graduates. IUP Journal of Soft Skills, 11(2), 7-24.

McCafferty, R. A. (2018). Business schools bulking up as competition intensifies. Crain's Cleveland Business, 39(21), 0001.

Millennials in the Workplace. (2016). Rock Products, 119(12), 18.

Pernsteiner, A. J. (2015). The Value of an Accounting Internship: What Do Accounting Students Really Gain? Academy of Educational Leadership Journal, 19(3), 223-233.

Peterson, S. (2018). EMBRACE CHANGE OR BECOME OBSOLETE: Internal auditors must grasp technological innovations and continually seek to evolve. Internal Auditor, 2.

Pan, G., \& Seow, P. (2016). Preparing accounting graduates for digital revolution: A critical review of information technology competencies and skills development. Journal of Education for Business, 91(3), 166-175. doi:10.1080/08832323.2016.1145622

Phillips, C. R., \& Trainor, J. (2014). Millenial Students and the Flipped Classaroom. Journal of Business and Educational Leadership. 5(1), 102-112. 
Rîndaşu, S. M. (2017). Emerging information technologies in accounting and related security risks-what is the impact on the Romanian accounting profession. Accounting and Management Information Systems, 16(4), 581-609.

Scarpati, S., \& Johnson, P. (2012). Teaching and Advising a New Generation of Accounting Students. The CPA Journal, August 14-17.

Shoztic, K., Bible, W., Nelson, E., \& Stein, S. (2016). DEVELOPING TOMORROW'S AUDITOR. Financial Executive, 3240-44.

Sînziana-Maria, R. (2016). Information security - a new challenge for the young and future financial auditors. Audit Financiar, 14(138), 670-679 (2016), (138), 670. doi:10.20869/AUDITF/2016/138/670

Spraakman, G., O’Grady, Winifred, Askarany, D., \& Akroyd C. (2015). Employers' Perceptions of Information Technology Competency Requirements for Management Accounting Graduates. Accounting Education: and international journal, 24(5), 403-422.

Steinmetz, K. (2017). Move Over, Millennials: How Generation Z Is Disrupting Work As We Know It. (U.S./Careers and Workplace). Time, 27.

Succi, C. (2015). Soft Skills for the Next Generation: Toward a comparison between Employers and Graduate Students' Perceptions. Sociologia Del Lavoro, 137, 244-256.

Tholen, G., Relly, S. J., Warhurst, C., \& Commander, J. (2016). Higher education, graduate skills and the skills of graduates: the case of graduates as residential sales estate agents. British Educational Research Journal, 42(3), 508-523.

Tulgan, B. (2015). Bridging the Millennial Soft Skills Gap. Government Executive, 1.

Vasarhelyí, M. A., Warren Jr., D., Teeter, R. A., \& Títera, W. R. (2014). Embracing the Automated Audit. Journal of Accountancy, 217(4), 34-37.

Vogelsong, J. (2018). a human touch: Seeing a need, CPA firms add HR-related services. Central Penn Business Journal, 34(10), 13.

Weaver, P., \& Kulesza. M. (2014). Critical Skills for New Accounting Hires: What's Missing from Traditional College Education? Academy of Business Research Journal, 4, 34-49.

Wong, E., \& Incognita, E. T. (2009, April 24). www. sciencemag. org SCIENCE VOL 324(429). 


\section{APPENDIX}

FIGURE 1

WHO SHOULD BE PROVIDING NEEDED SKILLS TO GRADUATING ACCOUNTING STUDENTS

\begin{tabular}{|c|c|c|}
\hline EMPLOYERS & $\begin{array}{c}\text { BOTH EMPLOYERS \& } \\
\text { UNIVERSITIES }\end{array}$ & UNIVERSITIES \\
\hline $\begin{array}{l}\text { Displaying } \\
\text { professional } \\
\text { manner } \\
\text { ERP systems } \\
\text { Foreign languages } \\
\text { Problem-solving } \\
\text { skills } \\
\text { Relational } \\
\text { databases } \\
\text { Working in teams }\end{array}$ & $\begin{array}{l}\text { Business Analytics } \\
\text { Displaying } \\
\text { professional } \\
\text { manner } \\
\text { Foreign languages } \\
\text { Listening skills } \\
\text { Persuasion skills } \\
\text { Problem-solving } \\
\text { skills } \\
\text { Relational } \\
\text { databases } \\
\text { Strategic } \\
\text { prospective } \\
\text { Working in teams }\end{array}$ & $\begin{array}{l}\text { Applying and } \\
\text { interpreting } \\
\text { statistical methods } \\
\text { Attitude of respect } \\
\text { to clients } \\
\text { Continuous auditing } \\
\text { Data mining } \\
\text { ERP systems } \\
\text { English language } \\
\text { competency } \\
\text { Highly technical AIS } \\
\text { systems } \\
\text { Time-management } \\
\text { skills }\end{array}$ \\
\hline
\end{tabular}

